\title{
Auditor economic incentives and going-concern opinions in a limited Litigious Continental European business environment: empirical evidence from Belgium
}

Citation for published version (APA):

Vanstraelen, A. (2002). Auditor economic incentives and going-concern opinions in a limited Litigious Continental European business environment: empirical evidence from Belgium. Accounting and Business Research, 32(3), 171-186. https://doi.org/10.1080/00014788.2002.9728966

Document status and date:

Published: 01/01/2002

DOI:

10.1080/00014788.2002.9728966

Document Version:

Publisher's PDF, also known as Version of record

Please check the document version of this publication:

- A submitted manuscript is the version of the article upon submission and before peer-review. There can be important differences between the submitted version and the official published version of record. People interested in the research are advised to contact the author for the final version of the publication, or visit the DOI to the publisher's website.

- The final author version and the galley proof are versions of the publication after peer review.

- The final published version features the final layout of the paper including the volume, issue and page numbers.

Link to publication

\footnotetext{
General rights rights.

- You may freely distribute the URL identifying the publication in the public portal. please follow below link for the End User Agreement:

www.umlib.nl/taverne-license

Take down policy

If you believe that this document breaches copyright please contact us at:

repository@maastrichtuniversity.nl

providing details and we will investigate your claim.
}

Copyright and moral rights for the publications made accessible in the public portal are retained by the authors and/or other copyright owners and it is a condition of accessing publications that users recognise and abide by the legal requirements associated with these

- Users may download and print one copy of any publication from the public portal for the purpose of private study or research.

- You may not further distribute the material or use it for any profit-making activity or commercial gain

If the publication is distributed under the terms of Article 25fa of the Dutch Copyright Act, indicated by the "Taverne" license above, 


\title{
Auditor economic incentives and going-concern opinions in a limited litigious Continental European business environment: empirical evidence from Belgium
}

\author{
Ann Vanstraelen*
}

\begin{abstract}
Theory predicts that auditor reporting behaviour may be influenced by the perceived consequences of disclosing going-concern uncertainty in the audit report (DeAngelo 1981, Watts and Zimmerman 1986). Krishnan and Krishnan (1996) and Louwers (1998) have addressed this issue empirically in a US context. The results of Krishnan and Krishnan (1996) suggested that one of the important factors in the auditor's opinion decision is the risk of litigation. The purpose of this study is to examine the relationship between auditor economic incentives and the propensity to issue going-concern opinions in a limited litigious business environment, Belgium. In spite of the low risk of litigation and the fact that most Belgian companies are privately held, various regulations have been put into effect to safeguard audit quality in Belgium. However, the results suggest that the auditor's going-concern opinion decision in Belgium is associated with factors relating to the perceived consequences of disclosing a goingconcern opinion. Specifically, the results suggest that auditors in Belgium are significantly less likely to issue going-concern opinions to clients that pay higher audit fees, and when the audit firm has lost a relatively high proportion of its clients in the preceding year. The auditor's going-concern opinion does not appear to be significantly influenced by the length of the auditor-client relationship, year of the auditor engagement period, and auditor type. The results of this study are to some extent different from the study by Louwers (1998), in which none of the incentive variables related to the auditor's loss function was significant.
\end{abstract}

\section{Introduction}

In the literature, it is argued that auditor reporting behaviour may be influenced by the perceived consequences of disclosing going-concern uncertainty in the audit report (DeAngelo, 1981a; Watts and Zimmerman, 1986). It is suggested that an auditor deciding to disclose going-concern uncer-

\footnotetext{
*The author wishes to thank the members of her doctoral committee: Ann Jorissen, Willem Buijink, John Christensen and Ignace De Beelde. The author is also grateful for helpful comments and suggestions provided by the participants of the 1998 IAAER/CIERA Conference in Chicago and the 1999 International Symposium on Audit Research in Los Angeles. Thanks also to the associate editor, Peter Moizer, an anonymous reviewer and my colleagues at Universiteit Maastricht: Roger Meuwissen, Frank Moers, Erik Peek, Caren Schelleman and Hans van Kranenburg. Special thanks are due to Marc DeFond and Steven Maijoor. Correspondence should be addressed to $\mathrm{Dr} A$. Vanstraelen at Universiteit Maastricht, Faculty of Economics and Business Administration, Maastricht Accounting and Auditing Research and Education Center, P.O. Box 616,6200 MD Maastricht, The Netherlands. Tel: + 31433883 755; Fax: + 31433884 876. E-mail: a.vanstraelen@berfin.unimaas.nl
}

The final version of this paper was submitted in March 2002. tainty in the audit report potentially faces economic trade-offs, in terms of expected costs of losing a client, being exposed to third-party lawsuits and loss of reputation (Krishnan and Krishnan, 1996: 566).

This issue was addressed empirically in a US context by Krishnan and Krishnan (1996) and Louwers (1998). Krishnan and Krishnan's results (1996: 583) suggested that one of the important factors in the auditor's opinion decision is the risk of litigation. Louwers (1998: 154) did not find evidence to support the contention that auditors' going-concern opinion decisions are systematically influenced by incentives associated with the auditor's loss function.

This study aims at examining the relation between auditor economic incentives and the propensity to issue going-concern opinions in a limited litigious business environment, i.e. Belgium. The choice of a continental European country is motivated by the fact that nearly all published studies on the auditor's going-concern opinion decision and its related aspects focus on an 
Anglo-American business environment. Hopwood et al. (1994: 426) stressed the importance of research on the auditor's going-concern opinion decision in other than Anglo-American countries.

Despite the low risk of litigation and the fact that most Belgian companies are privately held, various regulations have been put into effect to safeguard audit quality in Belgium. However, this study provides empirical evidence which suggests that the auditor's going-concern opinion decision in Belgium is associated with factors relating to the perceived consequences of disclosing a goingconcern opinion. In particular, auditors in Belgium appear to be significantly less likely to issue a going-concern opinion to a client that pays higher audit fees, and when the audit firm has suffered client losses in the preceding year. In addition, this study shows that the auditor's going-concern opinion decision is significantly related to: the financial condition of the client; the location of the client; a delay in the holding of the annual general meeting of shareholders, which may suggest lengthy auditor-client negotiations and extensive auditor testing; and bad news in the annual report of the Board of Directors, which tends to decrease the conflict of interest between the auditor and the client management.

The remainder of the paper is organised as follows. First, as a general background, prior research on the auditor's going-concern opinion decision is briefly discussed. Second, the characteristics of the Belgian audit services market are discussed. Third, the research design and research methodology are discussed. Fourth, the results of the analysis are presented. Finally, conclusions are drawn.

\section{Background}

During the past two decades, auditors' responsibility for assessing the appropriateness of the goingconcern assumption in the financial statements of their clients has become the subject of much debate in the auditing profession and considerable research by academics. This increased attention is due to the fact that auditors appear to be reluctant to disclose existing going-concern problems in their audit reports. Indeed, many companies in the year prior to bankruptcy receive an audit report in which no going-concern uncertainty is disclosed (Menon and Schwartz, 1987; Hopwood et al., 1991; Citron and Taffler, 1992; Carcello et al., 1997; Lennox, 1999a). Moreover, the ability of going-concern opinions to predict or identify failing companies is inferior to bankruptcy prediction models (Mutchler, 1985; Koh and Kilough, 1990; Hopwood et al., 1991; Nogler, 1995). This is a peculiar observation, as one would expect auditors, who after all have access to internal information, to have more relevant data at their disposal. This raises questions about auditors' behaviour in re- sponse to a going-concern uncertainty and how the auditor arrives at the going-concern opinion decision.

On the basis of the going-concern opinion literature, it can be stated that the auditor's goingconcern opinion decision consists of two stages (Krishnan and Krishnan, 1996: 567). In the first stage, the auditor evaluates information to form an initial impression of an entity's financial condition. In the second stage, the auditor will decide on the type of audit report to be issued. Referring to DeAngelo's (1981b) definition of audit quality, the first stage depends on the auditor's competence, while the second stage depends on the auditor's independence. Research has confirmed that auditors have the ability to identify a company with goingconcern problems (Kida, 1980; Campisi and Trotman, 1985; Citron and Taffler, 1992; Barnes and DenHuan, 1993). However, auditor independence has been questioned. It has been suggested in the literature that if an auditor acts as a rational economic agent, the auditor may be influenced by the perceived consequences of issuing a goingconcern report (DeAngelo, 1981a; Watts and Zimmerman, 1986). Risk of litigation, risk of loss of reputation and risk of audit loss are factors suggested in the literature which may relate to the economic trade-offs faced by the auditor (Krishnan and Krishnan, 1996: 566). Consequently, these factors could influence the auditor's going-concern opinion decision. Audit loss subsequent to the issuance of a going-concern opinion can occur due to auditor switching or due to bankruptcy of the client. The belief that a client will go bankrupt as a result of a going-concern uncertainty disclosure in the audit report is known in the literature as the self-fulfilling prophecy hypothesis (Mutchler, 1984: 24). The risk of litigation and risk of loss of reputation may have a positive effect on auditor independence, while the risk of audit loss may compromise auditor independence.

Two previous studies (Krishnan and Krishnan, 1996; Louwers, 1998) based on US data examined the role of economic trade-offs in the auditor's opinion decision. Louwers (1998: 154) did not find evidence to support the contention that auditors' going-concern opinion decisions are systematically influenced by incentive factors associated with the auditor's loss function. The following incentive factors were included in the study: prospective audit fees, the length of the auditorclient relationship, recent auditor litigation, client losses and the existence of previously disclosed evidence of going-concern difficulties. Krishnan and Krishnan (1996: 583) provided evidence that the auditor's litigation risk is an important factor in the auditor's opinion decision. Auditors in the US may perceive that the risk of litigation exceeds the potential losses of not disclosing going-concern 
uncertainty. The results of a study based on Flemish companies' (Vanstraelen, 1999: 53) suggest that recent client loss on the part of the auditor appears to moderate the willingness of the auditor to disclose going-concern uncertainty. Caution is needed with respect to the generalisation of these results given the small sample size and the fact that the observations relate to one year and to one part of the country.

Theoretical research (Melumad and Thoman, 1990; Dye, 1993; Acemoglu and Gietzmann, 1997) has demonstrated the crucial role legal liability plays in safeguarding auditor independence. Analytically, it has also been shown that it is less costly for auditors to be conservative with clients that are nearing bankruptcy, since the type II error cost (misclassification of a failing company as a non-failing company) is typically larger than the type I error cost (misclassification of a non-failing company as a failing company) (Matsumara et al., 1997: 731). Recently, these theoretical findings were supported by empirical evidence in the US (DeFond and Subramanyam, 1999). Moreover, Carcello and Palmrose (1994: 2) reported that bankruptcy is one of the most frequent sources of litigation against auditors: $74 \%$ of the auditors of clients that go bankrupt are sued.

The purpose of this study is to assess whether the auditor's propensity to disclose going-concern uncertainty is influenced by economic incentives related to the auditor's loss function in a limited litigious Continental European business environment. The incentive variables considered in this study are: expected audit revenues, recent loss of audit clients, tenure and auditor type. The first three incentive variables were also used by Louwers (1998). It has been shown that litigation rates in Continental Europe are rather low in comparison with the US and the UK (Kinney, 1994; Mueller et al., 1994; Gietzmann and Quick, 1998). This study will be carried out in Belgium: a typi-

\footnotetext{
' Belgium consists of two major parts: Flanders and Wallonia. Flanders is the Flemish-speaking part, while Wallonia is the French-speaking part.

${ }^{2}$ The following description is based on Lefebvre and Flower (1994), Block and Jorissen (1995), Buijink et al. (1996), Meuwissen (1999); Vanstraelen (2000); and Gaeremynck and Willekens (2001).

${ }^{3}$ The Law on Bookkeeping considers a company to be large if it either exceeds more than one of the following criteria: (i) average number of persons employed on annual basis is 50 ; (ii) annual turnover, exclusive VAT, 6,250,000; (iii) balance sheet total, $3,125,000$ or whose average number of employees during the period exceeds 100 .

${ }^{4}$ The Institute of Auditors is a public institute under the authority of the Ministry of Economic Affairs and is assisted by the High Council for Auditing and Accounting. Belgian Company Law requires that statutory audits of entities under prudential control (e.g. listed companies, banks and other financial institutions, insurance companies and hospitals) can only be performed by auditors approved by the various official bodies regulating those industries.
}

cal Continental European country. In Belgium, accounting is governed by legal rules, banks and other financial institutions play a central role in corporate financing, financial reporting is strongly influenced by tax considerations and financial reporting is creditor oriented (Lefebvre and Flower, 1994; Block and Jorissen, 1995). In addition, most Belgian firms are privately held and ownership is concentrated in both family-owned as well as public companies. Given the rather limited litigious business environment in Continental Europe, concern arises as to whether the independence of auditors is compromised or whether it is safeguarded by other incentives.

\section{Characteristics of the Belgian audit services market ${ }^{2}$}

The purpose of this section is to provide an overview of the Belgian institutional framework within which the results of this study should be interpreted. Audit regulation in Belgium is discussed by focusing on the following aspects: audit requirement; auditor independence; auditor liability; and auditor reporting.

\subsection{Audit requirement}

The statutory audit of companies in Belgium is governed by Company Law. Companies that meet specific legal form and size criteria ${ }^{3}$ are required to have their financial statements audited by a member of the Institute of Auditors. ${ }^{4}$ The statutory auditor needs to examine the company's financial situation and its financial statements, consisting of the balance sheet, the profit and loss account and the notes. Subsequently, the auditor has to form an opinion as to whether the financial statements convey a faithful picture (Nobes, 1993: 42) of the company's shareholders' equity and the financial position at the balance sheet date, and whether the year's results are in accordance with the legal and administrative requirements. The audit has to be conducted in accordance with the generally accepted auditing standards promulgated by the Institute of Auditors (Block and Jorissen, 1995). The General Meeting of Shareholders appoints the statutory auditor on the basis of a recommendation by the Board of Directors. The term of appointment is three years, which can subsequently be renewed without limitation for further three-yearly periods. A works council has the right to refuse the appointment of the nominee auditor and defend this position in court. There are works' councils in all Belgian companies and institutions that employ on average more than one hundred workers. The works council is a body with equal representation of employers and employees. Its purpose is to implement social legislation. The works council is entitled to adequate financial and economic information about the entity. Auditors can only be dis- 
missed during their mandate under very exceptional circumstances. ${ }^{5}$ Resignation of the auditor during his mandate is likewise restricted.

\subsection{Independence}

The statutory auditor in Belgium is subject to a strict code of ethics and auditing standards. Many of the regulations are aimed at protecting auditor independence. The principal regulations concerning auditor independence are the following. Auditors are not allowed to accept an engagement when they have a personal or commercial relationship with the client, a financial interest in the client or fee-dependence. Moreover, it is prohibited for an auditor to accept an engagement if he has been a director or manager of that client in the past three years. It is also forbidden for audit firms to provide other services (e.g. tax, legal services, consulting) to an audit client within the same legal entity, with the exception of the provision of bookkeeping and accounting services on an ad hoc and non-recurring basis. Auditors are not allowed to be employed full-time outside the auditing profession. If so, they lose their licence. Furthermore, all forms of advertising and unsolicited offerings of services to the public in general are forbidden. The auditing profession has also created some mechanisms to monitor its members. Auditors are required to report to the Institute of Auditors the number of hours worked for and the fee charged to each of their clients. Moreover, each audit firm is subjected to a peer review at least once every five years. Finally, the Institute of Auditors imposes disciplinary sanctions against auditors violating the Ethical Code.

\subsection{Liability}

The auditor's report and the financial statements have to be filed with the Belgian National Bank and are publicly available. Legal action against an auditor in Belgium can be undertaken by the client company, its shareholders, or any interested third party. Belgium has adopted the proportional liability system, placing liability upon the defendants according to their contribution to the damage. However, liability can neither be capped by law nor by contract. Belgian statutory auditors are not required to maintain professional indemnity insurance. Legal action against a statutory auditor can be undertaken within the five years after the issue of the auditor's report. Litigation rates in Belgium

\footnotetext{
${ }^{5}$ For example, physical incapacity or negligence resulting in a loss of confidence.

${ }^{6}$ It is noted that during the period under study 1992-1996, the subtype of audit opinion 'unqualified audit opinion with an explanatory paragraph' was not yet recognised by the Belgian Institute of Auditors. However, 4 out of the 1,176 companies in our sample did receive an unqualified report that mention going-concern problems. These four reports were coded as reports disclosing a going-concern uncertainty.
}

are low (Vanstraelen, 1999; Gaeremynck and Willekens, 2001). This is a typical characteristic of countries which have government-prescribed accounting standards that are rather conservative, while banks or the government are the major providers of capital (Mueller et al., 1994).

\subsection{Audit report}

The auditing standards with respect to the form and content of the Belgian audit report are issued by the Institute of Auditors. The Belgian auditing profession distinguishes between six types of audit opinions to be issued under specific circumstances: an unqualified opinion; an unqualified opinion with an explanatory paragraph; a qualified opinion; a qualified opinion with an explanatory paragraph; a disclaimer of opinion and an adverse opinion. An important characteristic of the Belgian audit report is the fact that it contains two parts. The first part of the audit report, which is similar to the audit report in most countries, provides an opinion on the financial statements. The statutory auditor describes the applied auditing standards, the objectives of the audit, how he has carried out the audit, and whether he has obtained all the required information and explanations from the directors and management. The auditor concludes with an opinion on whether the annual accounts give a faithful picture (Nobes, 1993: 42) of the company's net worth, the financial position and the results of the year. The second part of the Belgian audit report is different from most countries as it provides additional statements and information, which are required by Company Law (Article 144). In particular, the auditor expresses an opinion on whether the annual report of the Board of Directors contains the information required by law and agrees with the annual accounts. The additional statements and information are primarily for the use of the works council in order to better inform and protect employees.

If the auditor is confronted with significant going-concern problems, he will draw attention to this fact in the first part of his audit report. The auditor is also required to modify the second part of his report if he feels that the annual report does not contain the information required by law, i.e. a justification for the continuation of business operations if necessary. The following situations may occur. First, if the Board of Directors has described the going-concern uncertainty correctly in its annual report or in the notes to the financial statements, the statutory auditor will issue an unqualified report regarding this item. However, he is required to elucidate his judgment in an explanatory paragraph ${ }^{6}$ in which attention is drawn to the existence of a risk in terms of continuity. Second, if the Board of Directors has provided inappropriate information in the notes to the annual 
statements or in the annual report, the statutory auditor will issue a qualified opinion. Third, a disclaimer of opinion is justified if the statutory auditor is unable to collect the required information for evaluating the going-concern status of the company. Finally, if the statutory auditor concludes after his audit that the going-concern assumption used by the Board of Directors for the preparation of the annual statements is inappropriate, he will issue an adverse opinion. If there is a difference of opinion regarding the going-concern assumption used by the Board of Directors, he will issue an adverse opinion that mentions explicitly that this difference of opinion exists.

\section{Research design and research methodology \\ 4.1. Sample}

While standard American databases like Compustat allow going-concern researchers to search on the type of audit report (standard unqualified report, modified unqualified report, qualified report, disclaimer report and adverse report), this is not possible with Belgian databases. ${ }^{7}$ Therefore, a different sample design was chosen. The design of the study started from the entire population of large ${ }^{8}$ Belgian companies that went bankrupt in the period 1992-1996. For each large company that was declared bankrupt in the period 1992-1996, we attempted to collect the audit report on the financial statements submitted to the Belgian National Bank in the year prior to bankruptcy. Companies for which no data were available were excluded $(30 \%)$. Excluding companies belonging to the same group of companies $(6 \%)$ further reduced the number of bankrupt companies included in the sample. Only one bankrupt compa-

\footnotetext{
${ }^{7}$ CDROMs containing the financial statements of Belgian companies submitted to the Belgian National Bank.

8 A company is considered to be large if it either exceeds more than one of the following criteria: (i) average number of persons employed on annual basis is 50; (ii) annual turnover, exclusive VAT, BFr. $145 \mathrm{~m}$; (iii) balance sheet total, BFr. $70 \mathrm{~m}$ or whose average number of employees during the period exceeds 100. These size criteria were adjusted by Article I, Royal Decree 27 April 1995 into: annual turnover, exclusive VAT, BFr. $200 \mathrm{~m}$ and balance sheet total, BFr. $100 \mathrm{~m}$. It is noted that the size criteria were revised again recently and apply to companies with fiscal year end 31 December 1999: annual turnover, exclusive VAT, $6,250,000$ and balance sheet total, $3,125,000$.

9 The DSCORE is calculated from the general multiple linear discriminant model, developed for Belgian companies, consisting of the following ratios: accumulated profit (loss) \& reserves/total liabilities; taxes and social security charges/short-term external liabilities; cash/restricted current assets; work in progress \& finished goods/restricted current assets; short-term financial debts/ short term external liabilities. The DSCORE of the general bankruptcy prediction model has a prediction accuracy of $75.6 \%$ when using the optimal cut-off point of DSCORE $=0.1304$ (Ooghe and Van Wymeersch, 1991; Ooghe, Joos and de Bourdeaudhuij, 1995).
}

ny, usually the parent company of the group of bankrupt companies was included in the sample. This procedure was followed to avoid double counts, since the same auditor would issue the same audit opinion to all companies of the group that went bankrupt. The final sample contained 392 bankrupt companies. Subsequently, a second sample was created containing 392 financially stressed non-bankrupt large Belgian companies. Using common criteria in the literature (Mutchler, 1985; Hopwood et al., 1994), a company is considered to be financially stressed if it has either suffered an operational loss, a bottom line loss, or negative retained earnings in the current year or previous two years or has a negative working capital in the previous two years.

Finally, a control sample containing 392 financially non-stressed non-bankrupt large Belgian companies was created. Menon and Schwartz (1985: 255) stressed the importance of matching control groups of companies by industry and size. Hence the three samples were matched by year, industry (using four-digit NACE-code) and size (based on total assets). The sample design of this study is similar to the UK study of Citron and Taffler (1992). However, in this study an additional control sample is created containing financially non-stressed non-bankrupt firms. For each of the three samples of companies, Table 1 illustrates the financial condition and the proportions of type of audit reports issued to these companies.

The financial condition of a company is measured by the general discriminant score (DSCORE) of a standard bankruptcy prediction model developed for Belgian companies. ${ }^{9}$ The descriptive statistics in Table 1 show that the sample of bankrupt companies is more financially stressed compared with the sample of financially stressed non-bankrupt companies. Table 1 further shows that after analysing the audit reports issued to the 392 bankrupt firms in the sample one year prior to bankruptcy, it appears that only in $37 \%$ of the cases is a going-concern uncertainty disclosed. In other words, in $63 \%$ of the cases auditors did not mention going-concern problems one year prior to bankruptcy. Comparison of this base-rate frequency with similar research in the US shows that the proportion of bankrupt companies with a goingconcern qualification in the US is on average higher, ranging from $39 \%$ to $54 \%$ prior to SAS-59 and from $54 \%$ to $62 \%$ since the implementation of SAS-59 $9^{10}$ (Koh, 1991; Raghunandan and Rama, 1995; Carcello et al., 1997). This finding is in line with the expectation that auditors in continental European countries are more reluctant to express going-concern uncertainty in the audit report, possibly due to the differences in the legal and institutional environment between continental European countries and the US. 


\begin{tabular}{|c|c|c|c|}
\hline $\begin{array}{l}\text { GLOBAL: } \\
1992-1996\end{array}$ & $\begin{array}{l}\text { Sample bankrupt } \\
\text { firms } \\
n=392\end{array}$ & $\begin{array}{l}\text { Sample financially } \\
\text { stressed non- } \\
\text { bankrupt firms } \\
n=392\end{array}$ & $\begin{array}{l}\text { Sample final } \\
\text { non-stressed } \\
\text { bankrupt fir } \\
n=392\end{array}$ \\
\hline DSCORE $^{1}$ & $\begin{array}{l}\text { mean: }-2.77 \\
\text { 25th percentile.: }-1.68 \\
\text { median: }-0.58 \\
\text { 75th percentile.: } 0.07\end{array}$ & $\begin{array}{l}\text { mean: }-0.47 \\
\text { 25th percentile.: }-0.90 \\
\text { median: }-0.09 \\
\text { 75th percentile.: } 0.56\end{array}$ & $\begin{array}{l}\text { mean: } 1.48 \\
25 \text { th percent } \\
\text { median: } 1.2 \\
75 \text { th percent }\end{array}$ \\
\hline $\begin{array}{l}\text { Unqualified audit } \\
\text { report }\end{array}$ & $163(41.6 \%)$ & $293(74.8 \%)$ & $370(94.4 \%)$ \\
\hline \multicolumn{4}{|l|}{$\begin{array}{l}\text { Other than unqualified } \\
\text { audit report: }\end{array}$} \\
\hline $\begin{array}{l}\text { because of going- } \\
\text { concern uncertainty } \\
\text { by issuing: } \\
\text { qualified opinion } \\
\text { disclaimer of opinion } \\
\text { adverse opinion }\end{array}$ & $\begin{array}{c}102(70 \%) \\
35(24 \%) \\
8(6 \%)\end{array}$ & $\begin{array}{l}49(92 \%) \\
4(8 \%) \\
0(0 \%)\end{array}$ & $0(0 \%)$ \\
\hline $\begin{array}{l}\text { because of other } \\
\text { reasons } \\
\text { by issuing: }\end{array}$ & $84(21.4 \%)$ & $46(11.7 \%)$ & $22(5.6 \%)$ \\
\hline qualified opinion & $60(71 \%)$ & $34(74 \%)$ & $17(77 \%)$ \\
\hline disclaimer of opinion & $21(25 \%)$ & $12(26 \%)$ & $5(23 \%)$ \\
\hline adverse opinion & $3(4 \%)$ & $0(0 \%)$ & $0(0 \%)$ \\
\hline
\end{tabular}

'DSCORE: The financial condition of a company is measured by the general discriminant score of a standard bankruptcy prediction model developed for Belgian companies. The DSCORE is calculated from the general multiple linear discriminant model consisting of the following ratios: accumulated profit (loss) \& reserves/total liabilities; taxes and social security charges/short-term external liabilities; cash/restricted current assets; work in progress \& finished goods/restricted current assets; short-term financial debts/ short term external liabilities. The DSCORE of the general bankruptcy prediction model has a prediction accuracy of $75.6 \%$ when using the optimal cut-off point of DSCORE=0.1304 (Ooghe and Van Wymeersch 1991, Ooghe, Joos and de Bourdeaudhuij 1995).

${ }^{10}$ In the US the auditor's responsibility with respect to the going-concern issue has been increased by replacing in 1988 SAS-34 ('The auditor's considerations when a question arises on an entity's continued existence') with SAS-59 ('The auditor's consideration of an entity's ability to continue as a going concern'). The main consequence of the change of standard is that the task of assessing a company's ability to continue as a going concern has been transformed from a negative into an affirmative duty.

"Gaeremynck and Willekens (2001) selected a sample of 114 Belgian companies that had terminated their business operations due to bankruptcy or voluntary liquidation in 1995 or 1996, and reported that $45.61 \%$ received an unqualified opinion. A subdivision of the results between bankrupt and liquidated firms showed that of the 52 bankrupt firms $21 \%$ received an unqualified opinion in the year prior to bankrupt$\mathrm{cy}$, whereas of the 62 liquidated firms $66 \%$ received an unqualified opinion in the year prior to liquidation. It is noted that the 392 bankrupt companies included in my sample represent all companies that were declared bankrupt in the period 1992-1996 of which the audit report one year prior to bankruptcy was available.
Besides focusing on going-concern uncertainty disclosure (GCUD), one can also look at all audit reports issued other than unqualified. It appears that auditors do not mention any problem in $41.6 \%$ of the cases." When comparing this percentage with the percentage of no going-concern uncertainty disclosure, one could deduce that there are three types of auditor reporting behaviour:

1. Issue a qualified opinion, disclaimer of opinion or adverse opinion in which going-concern uncertainty is disclosed;

2. Issue a qualified opinion, disclaimer of opinion or adverse opinion without disclosing goingconcern uncertainties;

3 . Issue an unqualified audit report without mentioning any kind of problem.

The second type of auditor reporting behaviour could be considered as a kind of substitution. The 
auditor substitutes the disclosure of going-concern problems by the disclosure of other types of problems. The proportions of other types of problems disclosed in the audit reports for bankrupt companies that are not unqualified (qualified opinion, disclaimer of opinion and adverse opinion) are: valuation assets (23\%); bad debts $(21 \%)$; weak system of internal control (16\%); first year of first audit mandate $(12 \%)$; contingent liabilities $(7 \%)$; scope limitation $(2 \%)$; more than one of these problems $(19 \%)$. These other types of problems could actually lead to bankruptcy, but it is not explicitly mentioned. It is left to the judgment of the users of the financial statements.

Table 1 further shows that of the 392 financially stressed non-bankrupt companies in year $t$, nearly $75 \%$ received an unqualified audit report in year $\mathrm{t}-$ 1. In $13.5 \%$ of the cases, potential going-concern problems were disclosed. Approximately $12 \%$ of the companies received a qualified report, disclaimer of opinion or adverse opinion, without an explicit going-concern uncertainty disclosure. Finally, Table 1 shows that the total control sample of financially non-stressed non-bankrupt companies contains 392 firms of which nearly $95 \%$ of the firms received an unqualified audit report.

\subsection{Model variables}

\section{INCENTIVE VARIABLES}

The primary focus of this study is to see whether auditors' incentives related to the auditor's loss function significantly influence the auditor's goingconcern opinion decision. Four variables are considered which relate to the auditor's loss function.

First, the economic interest of the auditor in a client is a crucial factor in the auditor's loss function. Two variables are used to measure the economic interest of an auditor in a client. The first variable is the auditor's revenues from the auditorclient relationship (LNFEE). It is expected that higher audit fees will decrease the willingness of the auditor to disclose going-concern uncertainty. Given the fact that information on actual audit fees is not publicly available, a proxy is needed. Audit fees are proxied by the natural logarithm of the sum of operational and financial revenues. This proxy is supported by the fact that the Belgian Institute of Auditors (IBR) developed scales for audit fees, based on the average number of audit working hours, which is considered to depend on the sum of total assets, operational and financial revenues. Total assets are not included in the audit fee proxy since it was one of the matching criteria for the non-bankrupt companies. The fact that there may be economies of scale in auditing, in the sense that large audits cost less per unit of asset or transaction audited than small audits, is usually dealt with by making the size variable a logarithmic function (Pong and Whittington, 1994).
The second variable is recent loss or gain of audit clients (CLIENTLOSS) to measure the economic interest of an auditor in a client. Recent client loss or gain was measured by the net change in the number of clients during the previous year, scaled by the total number of clients of the audit firm. ${ }^{12}$ Recent loss of audit clients may either increase the economic incentives of the audit firm to retain its current clients or may be related to audit firm conservatism (Louwers, 1998: 148).

The third variable is the type of auditor: Big 6 audit firm or non-Big 6 audit firm (B6NB6). ${ }^{13}$ Large audit firms are assumed to deliver better quality (DeAngelo, 1981b; Palmrose, 1988; Davidson and Neu, 1993; Lennox, 1999b) by being not only more capable of discovering a breach in the client's accounting system but also more willing to disclose the breach due to reputation concerns. Therefore it is expected that Big 6 audit firms will be more likely to disclose goingconcern uncertainty compared to non-Big 6 audit firms, all other things equal.

Fourth, the length of the auditor-client relationship (TENURE) may also be related to the auditor's loss function and affect the auditor's going-concern opinion decision. Based on the common perception that long tenure would compromise auditor independence (Levinthal and Fichman, 1985; Deis and Giroux, 1992), it is expected that long tenure will decrease the likelihood of the auditor to disclose going-concern uncertainty.

Finally, Belgian legislation requires a minimal length of the audit mandate of three years. During their mandate, auditors can be dismissed only under very exceptional circumstances. The audit mandate can be renewed without limitation, but always for three-yearly periods. Therefore, it is questioned whether the auditor's reporting behaviour in the first years of the audit mandate differs from the last year of the mandate (MANDATE). It could be expected that the incumbent auditor is more willing to make compromises with the client's management in the last year of his official mandate in the hope of renewing his mandate.

It is acknowledged that there may be other incentive variables related to the auditor's loss function which are not captured by the model. An example would be the provision of management advisory services. The impact of the provision of management advisory services on the auditor's reporting behaviour could not be measured. In Belgium, management advisory services are pro-

\footnotetext{
${ }^{12}$ An interesting alternative way to measure client loss would be to take into account the size of clients lost/gained. However, the cost of manual collection of these data in Belgium is prohibitive.

${ }^{13}$ The data of this study relate to the period 1992-1996. In that period, there were still six Big audit firms instead of the current Big 5 audit firms.
} 
vided by separate legal entities that are not required to make these data available.

\section{CONTROL AND INSTITUTIONAL VARIABLES}

In addition to the incentive variables relating to the auditor's loss function, some control and institutional variables were included in this study in order to reduce the likelihood of correlated omitted variables. The choice of variables is supported by prior research on the auditor's going-concern opinion decision and institutional factors. The following variables were considered. The first variable is a bankruptcy dummy (BANKRUPT), which serves as an ex-post control for financial health. It can be expected that there is a strong correlation between bankruptcy and the likelihood of a goingconcern uncertainty disclosure.

The second variable is the time lag between the closing of the fiscal year and the submission of the financial statements to the Belgian National Bank. In this respect, a distinction is made between a delay of the annual general meeting of shareholders (GMDELAY) and a submission lag (SUBM$\mathrm{LAG})^{14}$ of the financial statements to the Belgian National Bank. Belgian Company Law requires that the annual general meeting of shareholders takes place within six months after the closing of the fiscal year. The maximum submission time of the financial statements to the Belgian National Bank is thirty days after the annual general meeting of shareholders. It can be expected that companies with financial difficulties tend to delay the holding of the annual general meeting of shareholders and the submission of the financial statements to the Belgian National Bank and are more likely to receive a going-concern uncertainty disclosure. A delay of the annual general meeting can be expected due to lengthy auditor-client negotiations that go with the disclosure of a going-concern uncertainty in the audit report. A submission lag can be expected since problem companies may want to defer potentially negative consequences

\footnotetext{
${ }^{14} \mathrm{~A}$ combination of the two variables, GMDELAY and SUBMLAG, into one LAG variable (lag between year-end and submission date) results in a significant positive regression coefficient of the LAG variable. The reason why I split the total lag into a GMDELAY and a SUBMLAG is to get more refined results. The results show that only the GMDELAY variable is significant, but not the SUBMLAG variable.

${ }_{15}$ The bankruptcy ratio, defined as the number of bankruptcies divided by the number of establishments, is the highest in Brussels, on average 0.39 during the period 1991-1996, followed by Wallonia, on average 0.28 and Flanders, 0.22 . The number of bankruptcies divided by the total number of companies follows the same pattern, ranging on average from 0.027 in Brussels during the period 1992-1996, to 0.020 in Wallonia and 0.017 in Flanders (calculations based on data provided by the NIS).

${ }^{16}$ It is noted that the causal relationship is difficult to disentangle. However, legally the report of the Board of Directors should be issued prior to the auditor's report.
}

related to the public announcement of the receipt of an audit report disclosing a going-concern uncertainty.

The third variable is the location of the client company. A distinction is made between whether the company is located in Brussels (LOCB), Wallonia (LOCW) or Flanders (LOCF, region of reference). Given the fact that the probability of bankruptcy is the highest in Brussels, followed by Wallonia and Flanders, ${ }^{15}$ it could be expected that a competent auditor would take the economic condition of the country into account.

Finally, the institutional variable bad news in the annual report of the Board of Directors (BADNEWS) is included in the model. Belgian Company Law requires an auditor to refer in the audit report to the annual report of the Board of Directors by stating whether it contains all the statutory information and whether it is in accordance with the financial statements. It is expected that bad news in the annual report of the Board of Directors will increase the likelihood of a goingconcern uncertainty disclosure in the audit report since it would reduce the conflict of interest between the auditor and the client's management. ${ }^{16}$

It is acknowledged that, notwithstanding these control and institutional variables, a potential omitted variable problem in the going-concern opinion model can never entirely be overcome. For example, the model does not control for persistence in audit reporting by including prior audit opinions. The data collection of prior audit opinions for all companies in our sample would have been prohibitively expensive. ${ }^{17}$

\subsection{Research methodology}

Given the special estimation problems related to binary dependent variables (Maddala, 1991), a logistic regression model was used to assess the incremental contribution of each incentive variable of interest while controlling for the variables described above. As mentioned, three choice-based samples were drawn with unequal population rates. The number of bankrupt companies is smaller than the number of financially stressed nonbankrupt companies, which is in turn smaller than the number of financially non-stressed non-bankrupt firms. Maddala (1991: 793) argues that if this choice-based sample is used to estimate a logit model, no weighting procedure is needed. The coefficients of the explanatory variables are not affected by the unequal sampling rates. It is only the constant term that is affected.

The model looks as follows:

GCUD $=\beta_{0}+\beta_{1}$ LNFEE $+\beta_{2}$ CLIENTLOSS $+\beta_{3}$ B6NB6 $+\beta_{4}$ TENURE $+\beta_{5}$ MANDATE $+\beta_{6}$ BANKRUPT $+\beta_{7}$ GMDELAY $+\beta_{8}$ SUBMLAG + $\beta_{9} \mathrm{LOCB}+\beta_{10} \mathrm{LOCW}+\beta_{11}$ BADNEWS $+\epsilon$ 
where:

GCUD Going-concern uncertainty disclosure in the audit report, binary variable $(G C U D=1$, in case going-concern uncertainty is disclosed).

LNFEE Natural logarithm of the firm audit fees for the client company, proxied by the sum of operational and financial revenues.

CLIENTLOSS Number of clients lost or gained by the audit firm during the previous year scaled by the annual number of firm clients (loss = -; gain $=+$ ).

B6NB6 Big 6 auditor or non-Big 6 auditor, binary variable $(B 6 N B 6=1$, in case of Big 6 auditor).

TENURE Length of the auditor-client relationship in years.

MANDATE Indicates in which year of his/her engagement period (mandate) the auditor is, binary variable (MAN$D A T E=1$, in case auditor is in last year of his/her official engagement period).

BANKRUPT Client company went bankrupt or survived, binary variable (BANK$R U P T=1$, in case of bankruptcy).

GMDELAY Number of months between the closing of the fiscal year and the date of the annual general meeting of shareholders.

SUBMLAG Number of days between the date of the annual general meeting of shareholders and the date of submission of the financial statements to the Belgian National Bank.

\footnotetext{
${ }^{17}$ In Belgium, audit opinions are not publicly available on CD-ROMS. They have to be bought as a hard copy from the National Bank.

${ }^{18}$ Article (103, Alarmprocedure) states: 'If net assets are less than $50 \%$ of the subscribed capital, the Board of Directors is required to convene the members of the General Meeting, who must decide on the basis of the Board's reorganisation plans whether or not to continue the entity. The diagnosis should take into account the specific characteristics of the entity at the closing date of the financial year, as well as events between this closing date and the date on which the Boards of Directors approves the annual statements and submits them to the General Meeting'. Article (104) says that 'if net assets are below the minimal amount any interested party may appeal to the court to dissolve the company'.
}

$L O C B$

Location of client company in Brussels, binary variable ( $L O C B$ $=1$, in case company is located in Brussels).

LOCW Location of client company in Wallonia, binary variable ( $L O C W$ $=1$, in case company is located in Wallonia).

BADNEWS Bad news score based on bad news in the annual report of the Board of Directors (bad news is considered to be disclosure of: important negative events after closing of the fiscal year; circumstances which can negatively influence the development of the company; application of Article 103/104 of Belgian Company Law; ${ }^{18}$ other bad news).

\section{Results and analysis}

\subsection{Descriptive statistics}

Table 2 presents summary descriptive statistics of the explanatory variables for the entire sample as well as for the sample of companies with and without a GCUD in the audit report.

Table 2 shows that companies with a going-concern uncertainty disclosure in the audit report generate significantly lower audit fees compared to companies without a going-concern uncertainty disclosure in the audit report. It is significantly more likely that companies without a going-concern uncertainty disclosure in the audit report were audited by an audit firm that recently lost audit clients. Big 6 audit firms disclose significantly more going-concern uncertainties in their audit reports compared with non-Big 6 audit firms. Goingconcern uncertainty disclosure in the audit report occurs significantly more in the case of a relatively short auditor-client relationship. A significant difference was also found for the variable mandate. However, the direction of the relationship is opposite to our expectations.

With respect to the control variables, it can be seen that, as expected, companies with a goingconcern uncertainty disclosure in the audit report have a bad financial condition, have significantly delayed their annual general meeting, are significantly more likely to be located in Brussels and Wallonia, and have significantly more bad news disclosed in the annual report of the Board of Directors. The only control variable that is not significant in the univariate analysis is a submission lag of the financial statements to the Belgian National Bank. Therefore, the SUBMLAG variable is dropped in the multivariate analysis. 
Table 2

Descriptive statistics and univariate analysis by grouping variable GCUD (Going-Concern Uncertainty Disclosure) over the period 1992-1996

\begin{tabular}{|c|c|c|c|c|}
\hline A. Descriptive statistics & Mean & Minimum & Maximum & Median \\
\hline LNFEE & 11.92 & 0 & 16.57 & 12.21 \\
\hline CLIENTLOSS ${ }^{1}$ & 6.62 & -100 & 100 & 11.11 \\
\hline B6NB6 & 0.26 & 0 & 1 & 0 \\
\hline TENURE & 3.76 & 0 & 9 & 4 \\
\hline MANDATE & 0.25 & 0 & 1 & 0 \\
\hline BANKRUPT & 0.33 & 0 & 1 & 0 \\
\hline GMDELAY & 5.42 & 1 & 17 & 5 \\
\hline SUBMLAG & 45.87 & 1 & 334 & 31 \\
\hline LOCB & 0.19 & 0 & 1 & 0 \\
\hline LOCW & 0.16 & 0 & 1 & 0 \\
\hline LOCF & 0.64 & 0 & 1 & 0 \\
\hline BADNEWS & 0.97 & 0 & 6 & 1 \\
\hline
\end{tabular}

I CLIENTLOSS: It is noted that in 22 cases of the 1176, the percentage of clients gained exceeded $100 \%$. These cases were considered as outliers and the percentage of clients gained was set at $100 \%$.

\begin{tabular}{|c|c|c|c|}
\hline $\begin{array}{l}\text { B. Univariate } \\
\text { analysis }\end{array}$ & $\begin{array}{l}\text { GCUD sample } \\
\text { Mean Rank } \\
\text { (Sum of Ranks) }\end{array}$ & $\begin{array}{l}\text { No GCUD sample } \\
\text { Mean Rank } \\
\text { (Sum of Ranks) }\end{array}$ & $\begin{array}{l}\text { Mann-Whitn } \\
\text { (Asymptotic } \\
\text { one-tailed) }\end{array}$ \\
\hline LNFEE & $\begin{array}{l}514.47 \\
(101351) \\
\text { 25th percentile: } 10.86 \\
\text { median: } 11.93 \\
\text { 75th percentile: } 12.72\end{array}$ & $\begin{array}{l}599.88 \\
(583683) \\
\text { 25th percentile: } 11.35 \\
\text { median: } 12.24 \\
\text { 75th percentile: } 13.01\end{array}$ & $\begin{array}{l}81848 \\
(0.001)^{* * *}\end{array}$ \\
\hline CLIENTLOSS & $\begin{array}{l}613.48 \\
(117788) \\
\text { 25th percentile: }-2.74 \\
\text { median: } 2.22 \\
\text { 75th percentile: } 11.34\end{array}$ & $\begin{array}{l}570.93 \\
(549802) \\
\text { 25th percentile: }-3.7 \\
\text { median: } 2.1 \\
\text { 75th percentile: } 11.11\end{array}$ & $\begin{array}{l}85636 \\
(0.053)^{*}\end{array}$ \\
\hline TENURE & $\begin{array}{l}490.66 \\
(95188.5) \\
\text { 25th percentile: } 2 \\
\text { median: } 3 \\
75 \text { th percentile: } 4\end{array}$ & $\begin{array}{l}598.54 \\
(578191.5) \\
\text { 25th percentile: } 3 \\
\text { median: } 4 \\
\text { 75th percentile: } 5\end{array}$ & $\begin{array}{l}76273.5 \\
(0.000)^{* * *}\end{array}$ \\
\hline GMDELAY & $\begin{array}{l}458.63 \\
\text { (90809) } \\
\text { 25th percentile: } 5 \\
\text { median: } 6 \\
75 \text { th percentile: } 6\end{array}$ & $\begin{array}{l}370.16 \\
(216911) \\
\text { 25th percentile: } 5 \\
\text { median: } 5 \\
\text { 75th percentile: } 6\end{array}$ & $\begin{array}{l}44920 \\
(0.000)^{* * *}\end{array}$ \\
\hline SUBMLAG & $\begin{array}{l}405.83 \\
(80353) \\
\text { 25th percentile: } 22.75 \\
\text { median: } 35 \\
\text { 75th percentile: } 64.25\end{array}$ & $\begin{array}{l}388 \\
(227366) \\
\text { 25th percentile: } 22 \\
\text { median: } 30 \\
\text { 75th percentile: } 51\end{array}$ & $\begin{array}{l}55375 \\
(0.169)\end{array}$ \\
\hline BADNEWS & $\begin{array}{l}625.67 \\
(91973) \\
\text { 25th percentile: } 1 \\
\text { median: } 2 \\
\text { 75th percentile: } 3\end{array}$ & $\begin{array}{l}(281707) \\
392.90 \\
\text { 25th percentile: } 0 \\
\text { median: } 1 \\
\text { 75th percentile: } 1\end{array}$ & $\begin{array}{l}24304 \\
(0.000)^{* * *}\end{array}$ \\
\hline
\end{tabular}


Table 2 (continued)

GCUD sample No GCUD sample Pearson $\chi^{2}$

(Asymptotic significance one-tailed)

\begin{tabular}{|c|c|c|c|}
\hline B6NB6 & $\begin{array}{l}\text { B6: } 30.1 \% \\
\text { NB6: } 69.9 \%\end{array}$ & $\begin{array}{l}\text { B6: } 25.3 \% \\
\text { NB6: } 74.7 \%\end{array}$ & $\begin{array}{l}1.874 \\
(0.085) *\end{array}$ \\
\hline MANDATE & $\begin{array}{l}\text { First years: } 71.1 \% \\
\text { Last year: } 28.9 \%\end{array}$ & $\begin{array}{l}\text { First years: } 75.5 \% \\
\text { Last year: } 24.5 \%\end{array}$ & $\begin{array}{l}1.667 \\
(0.098) *\end{array}$ \\
\hline LOCB & $\begin{array}{l}\text { Brussels: } 22.7 \% \\
\text { Not in Brussels: } 77.3 \%\end{array}$ & $\begin{array}{l}\text { Brussels: } 18.6 \% \\
\text { Not in Brussels: } 81.4 \%\end{array}$ & $\begin{array}{l}1.793 \\
(0.090) *\end{array}$ \\
\hline LOCW & $\begin{array}{l}\text { Wallonia: } 22.2 \% \\
\text { Not in Wallonia: } 77.8 \%\end{array}$ & $\begin{array}{l}\text { Wallonia: } 15 \% \\
\text { Not in Wallonia: } 85 \%\end{array}$ & $\begin{array}{l}6.26 \\
(0.006) * * *\end{array}$ \\
\hline LOCF & $\begin{array}{l}\text { Flanders: } 57.1 \% \\
\text { Not in Flanders: } 42.9 \%\end{array}$ & $\begin{array}{l}\text { Flanders: } 66.6 \% \\
\text { Not in Flanders: } 33.4 \%\end{array}$ & $\begin{array}{l}6.521 \\
(0.005) * * *\end{array}$ \\
\hline BANKRUPT & $\begin{array}{l}\text { Bankrupt: } 73.2 \% \\
\text { Non-bankrupt: } 26.8 \%\end{array}$ & $\begin{array}{l}\text { Bankrupt: } 25.3 \% \\
\text { Non-bankrupt: } 74.7 \%\end{array}$ & $\begin{array}{l}170.557 \\
(0.000) * * *\end{array}$ \\
\hline
\end{tabular}

where:

LNFEE Natural logarithm of the firm audit fees for the client company, proxied by the sum of operational and financial revenues.

CLIENTLOSS Number of clients lost or gained by the audit firm during the previous year scaled by the annual number of firm clients (loss $=-;$ gain $=+$ ).

B6NB6 Big 6 auditor or non-Big 6 auditor, binary variable (B6NB6 =1, in case of Big 6 auditor).

TENURE Length of the auditor-client relationship in years.

MANDATE Indicates in which year of his/her engagement period (mandate) the auditor is, binary variable (MANDATE = 1, in case auditor is in last year of his/her official engagement period).

BANKRUPT Client company went bankrupt or survived, binary variable $(B A N K R U P T=1$, in case of bankruptcy).

GMDELAY Number of months between the closing of the fiscal year and the date of the annual general meeting of shareholders.

SUBMLAG Number of days between the date of the annual general meeting of shareholders and the date of submission of the financial statements to the Belgian National Bank.

LOCB Location of client company in Brussels, binary variable ( $L O C B=1$, in case company is located in Brussels).

LOCW Location of client company in Wallonia, binary variable ( $L O C W=1$, in case company is located in Wallonia).

LOCF Location of client company in Flanders, binary variable ( $L O C F=1$, in case company is located in Flanders).

BADNEWS Bad news score based on bad news in the annual report of the Board of Directors (bad news is considered to be disclosure of: important negative events after closing of the fiscal year; circumstances which can negatively influence the development of the company; application of Article 103/104 of Belgian Company Law; other bad news). 





Table 3 presents the Pearson correlation matrix. As can be seen, the risk of bias due to strong correlations among the covariates is minimal.

\subsection{Logistic regression analysis}

The results of the logistic regression for the total sample are presented in Table 4. As can be seen the observations are well fit by the model, given the significant model's chi-square $(\mathrm{p}<0.0001)$ and the high association of predicted probabilities with observed responses $\left(85.1 \%\right.$ correct. $\left.^{19}\right)$

As shown in Table 4, the following incentive variables relating to the auditor's loss function appear to be significant explanatory variables. First, higher audit fees tend to decrease the likelihood of a going-concern uncertainty disclosure in a significant way ${ }^{20}$. Second, recent loss of audit clients appears to significantly moderate the willingness of the auditor to disclose going-concern uncertainty in the audit report. Big 6 auditors are not significantly more likely to disclose a going-concern uncertainty in the audit report. A subdivision of the total sample into bankrupt companies on the one hand, and non-bankrupt companies on the other hand, shows that the B6NB6 variable is not significant in either of the subsamples. ${ }^{21}$ The variables tenure and mandate are no longer significant when tested in a multivariate way.

The following control variables are significantly related to a going-concern uncertainty disclosure in the audit report: a bad financial condition of the client; a delay of the annual general meeting; a client company located in an economic weaker performing region; and bad news in the annual report of the Board of Directors. ${ }^{22}$

\section{Conclusions}

The purpose of this study was to assess whether the auditor's decision to disclose going-concern uncertainty is influenced by economic incentives related to the auditor's loss function. In contrast to prior research performed in a highly litigious US business environment, this study was done in a limited litigious Continental European business environment, i.e. Belgium. Despite the low risk of litigation and the fact that most Belgian companies are privately held, various regulations have been put into effect to safeguard audit quality in Belgium. However, this study provides empirical evidence to support the contention that the auditor's going-concern opinion decision in Belgium is significantly associated with factors surrogating the perceived consequences of disclosing a goingconcern uncertainty. Specifically, the results suggest that recent loss of audit clients appears to significantly moderate the auditor's going-concern opinion decision. Moreover, the results of the study suggest that higher audit fees decrease the willingness of the auditor to disclose going-con- cern uncertainty. No evidence was found that the auditor's going-concern opinion decision is significantly influenced by the length of the auditorclient relationship, ${ }^{23}$ year of mandate, and auditor type. This alleviates to some extent the concern that auditors may not act independently.

These results are to some extent different from the study of Louwers (1998), based on US data, in which no evidence was found for the fact that auditors' incentives play a role in the issuance of a going-concern modification. Indeed, none of the incentive variables related to the auditor's loss function was significant. A potential explanation for the difference in results could be that US auditors perceive the risk of litigation as higher than the potential losses of disclosing going-concern uncertainty. In other words, due to the high-litigious business environment in the US, litigation may be a dominant factor in the economic tradeoff made by the auditor and consequently other auditors' incentives may not come into play. This latter statement would also be consistent with both theoretical (Magee and Tseng, 1990) and empirical (DeFond and Subramanyam, 1999) research.

In addition, this study showed that the auditor's going-concern opinion decision is significantly related to: a bad financial condition; the location of a client company; bad news in the annual report of the Board of Directors which tends to decrease the conflict of interest between the auditor and the client management; and a delay of the annual general meeting of shareholders which may suggest lengthy auditor-client negotiations and extensive auditor testing.

${ }^{19}$ The prediction accuracy is based on a cut off value of $50 \%$. A cut off value of $33 \%$ (since one third of the companies in the total sample went bankrupt) results in a similar prediction accuracy rate of the model: $83.5 \%$.

${ }^{20}$ It is acknowledged that due to the absence of publicly available audit fee data, the audit fee proxy variable may seem less convincing. However, in our opinion, the fee result is not biased by merely capturing a client size effect, given that we control for the relation between client size and bankruptcy by including a bankruptcy dummy in the model. Therefore, we believe that the audit fee proxy does capture expected revenues and related independence concerns.

${ }^{21}$ Also Gaeremynck and Willekens (2001) did not find a significant reporting difference between Big 6 and non-Big 6 auditors for Belgian companies for which financial difficulties were obvious and bankruptcy followed. However, they did find evidence that Big 6 auditors issue more non-clean audit reports when financial problems are less explicit and voluntary liquidation follows.

22 Following Hopwood et al. (1994), it was checked whether the results might be biased because of including both financially stressed and non-stressed firms. To this end, the same logistic regression analysis was run for the subsample of bankrupt companies and financially stressed non-bankrupt companies. The results remain the same.

${ }^{23}$ It is noted that Vanstraelen (2000) did find evidence that auditors in Belgium are less willing to qualify audit reports in general (not specifically going-concern qualifications) in case of long tenure. 


\begin{tabular}{|c|c|c|c|c|}
\hline Variable & $\begin{array}{l}\text { Parameter } \\
\text { Estimate }\end{array}$ & $\begin{array}{l}\text { Standard } \\
\text { Error }\end{array}$ & $\begin{array}{l}\text { Wald } \\
\text { Chi-Square }\end{array}$ & $\begin{array}{l}\text { Significance } \\
p<\end{array}$ \\
\hline CONSTANT & -2.261 & 0.883 & 6.561 & $0.010^{* *}$ \\
\hline LNFEE & -0.245 & 0.062 & 15.442 & $0.000 * * *$ \\
\hline CLIENTLOSS & 0.010 & 0.004 & 6.763 & $0.009 * * *$ \\
\hline B6NB6 & 0.426 & 0.261 & 2.670 & 0.102 \\
\hline TENURE & -0.008 & 0.065 & 0.015 & 0.904 \\
\hline MANDATE & 0.177 & 0.257 & 0.476 & 0.490 \\
\hline BANKRUPT & 1.796 & 0.248 & 52.453 & $0.000 * * *$ \\
\hline GMDELAY & 0.243 & 0.078 & 9.725 & $0.002 * * *$ \\
\hline LOCB & 0.024 & 0.296 & 0.007 & 0.935 \\
\hline LOCW & 0.490 & 0.290 & 2.866 & $0.090^{*}$ \\
\hline BADNEWS & 0.753 & 0.102 & 54.062 & $0.000 * * *$ \\
\hline
\end{tabular}

$*^{* *}: \mathrm{p}<1 \% ; * *: \mathrm{p}<5 \% ; *: \mathrm{p}<10 \%$

-2 Log Likelihood: 530.187

Prediction accuracy: $85.1 \%$

Model chi-square: 223.890

Degrees of freedom: 10

Pseudo R-square: $29.69 \%$

Significance: 0.000

where:

LNFEE Natural logarithm of the firm audit fees for the client company, proxied by the sum of operational and financial revenues.

CLIENTLOSS Number of clients lost or gained by the audit firm during the previous year scaled by the annual number of firm clients (loss $=-$; gain $=+$ ).

B6NB6 Big 6 auditor or non-Big 6 auditor, binary variable (B6NB6 =1, in case of Big 6 auditor).

TENURE Length of the auditor-client relationship in years.

MANDATE Indicates in which year of his/her engagement period (mandate) the auditor is, binary variable (MANDATE = 1, in case auditor is in last year of his/her official engagement period).

BANKRUPT Client company went bankrupt or survived, binary variable (BANKRUPT $=1$, in case of bankruptcy).

GMDELAY Number of months between the closing of the fiscal year and the date of the annual general meeting of shareholders.

LOCB Location of client company in Brussels, binary variable ( $L O C B=1$, in case company is located in Brussels).

LOCW Location of client company in Wallonia, binary variable $(L O C W=1$, in case company is located in Wallonia).

BADNEWS Bad news score based on bad news in the annual report of the Board of Directors (bad news is considered to be disclosure of: important negative events after closing of the fiscal year; circumstances which can negatively influence the development of the company; application of Article 103/104 of Belgian Company Law; other bad news).

${ }^{1}$ The annual report of the Board of Directors was not available for all companies in the sample. For the bankrupt sample, the annual report of the Board of Directors was missing in 26.8\% (105) of the cases, for the sample financially stressed firms in $30.6 \%$ (120) of the cases and for the sample of financially non-stressed firms in $21.9 \%$ (86) of the cases. Therefore, the number of observations in the logistic regression analysis reduces to 865 . 
The results of this study are subject to the following limitations. First, due to data unavailability, it was not possible to work with actual fee data. Secondly, there may be other incentive variables related to the auditor's loss function which are not captured by the model. Thirdly, a potential omitted variable problem in the going-concern opinion model can never entirely be overcome.

Further research could provide additional evidence on whether these results hold in other limited litigious business environments.

\section{References}

Acemoglu, D. and Gietzmann, M. (1997). 'Auditor independence, incomplete contracts and the role of legal liability'. European Accounting Review, 6 (3): 355-375.

Barnes, P. and Den Huan, H. (1993). 'The auditor's goingconcern decision: some UK evidence concern in independence and competence'. Journal of Finance and Accounting, 20 (2): 213-228.

Block, H. and Jorissen, A. (1995). 'Belgium: individual accounts', in Ordelheide, D. and KPMG (eds.), Transnational Accounting, Macmillan, New York.

Buijink, W., Maijoor, S., Meuwissen, R. and van Witteloostuijn, A. (1996). The role, position, and liability of the statutory auditor within the European Union. MARC, Universiteit Maastricht.

Campisi, S. and Trotman, K.T. (1985). 'Auditor consensus in going-concern judgments'. Accounting and Business Research, 15 (Winter): 23-31.

Carcello, J.V. and Palmrose, Z. (1994). 'Auditor litigation and modified reporting on bankrupt clients'. Journal of Accounting Research, Supplement: 1-30.

Carcello, J.V., Hermanson, D.R., Huss, H.F. (1997). 'Research Notes. The effect of SAS No.59: How treatment of the transition period influences the results'. Auditing: A Journal of Practice and Theory, 16 (Spring): 114-123.

Citron, D.B. \& Taffler, R.J. (1992). 'The audit report under going-concern uncertainties: an empirical analysis' Accounting and Business Research, 22 (88): 337-345.

Davidson, R.A. and Neu, D. (1993). 'A note on the association between audit firm size and audit quality'. Contemporary Accounting Research, 9 (Spring): $479-488$.

De Angelo, L.E. (1981a). 'Auditor independence, 'low balling', and disclosure regulation'. Journal of Accounting and Economics, 3: 113-127.

De Angelo, L.E. (1981b). 'Auditor size and audit quality'. Journal of Accounting and Economics, 3: 183-199.

DeFond, M. and Subramanyam, K. (1999). 'Modified audit opinions, litigation risk and discretionary accruals'. Working paper, Leventhal School of Accounting, University of Southern California.

Deis, D.R. and Giroux, G.A. (1992). 'Determinants of audit quality in the public sector'. Accounting Review, July: $462-479$.

Dye, R. (1993). 'Discussion: Limiting auditors' liability'. Journal of Economics and Management Strategy, 2 (Fall): 435-443.

Gaeremynck, A. and Willekens, M. (2001). 'Audit reports and corporate demise: different tests in a different environment'. Working paper, Catholic University of Leuven. Gietzmann, M.B. and Quick, R. (1998). 'Capping auditor liability: The German experience'. Accounting, Organizations and Society, 23 (1): 81-103.
Hopwood, W., McKeown, J.C. and Mutchler, J. (1991). 'Towards an explanation of auditor failure to modify the audit opinions of audit qualifications'. Auditing: $A$ Journal of Practice and Theory, Supplement: 1-13.

Hopwood, W., McKeown, J.C. and Mutchler, J. (1994). 'A reexamination of auditor versus model accuracy within the context of the going-concern opinion decision'. Contemporary Accounting Research, 10 (Spring): 409-431.

Kida, T. (1980). 'An investigation into auditor's continuity and related qualification judgments'. Journal of Accounting Research, Autumn: 506-523.

Kinney, W.R. (1994). 'Audit litigation research: professional help is needed'. Accounting Horizons, June: 80-86. Koh, H.C. and Killough, L.N. (1990). 'The use of multiple discriminant analysis in the assessment of the going-concern status of an audit client'. Journal of Business Finance and Accounting, Spring: 179-192.

Koh, H.C. (1991). 'Model predictions and auditor assessment of going-concern status'. Accounting and Business Research, Autumn: 331-338.

Krishnan, J. and Krishnan, J. (1996). "The role of economic trade-offs in the audit opinion decision: an empirical analysis'. Journal of Accounting, Auditing and Finance, 11 (4): 565-586.

Lefebvre, C. and Flower, J. (1994). Belgium. European financial reporting series, Routledge, London.

Lennox, C.S. (1999a). 'The accuracy and incremental information content of audit reports in predicting bankruptcy'. Journal of Business, Finance and Accounting, 26 $(5 / 6): 757-778$.

Lennox, C.S. (1999b). 'Are large auditors more accurate than small auditors'. Accounting and Business Research, 29 (3): 217-227.

Levinthal, D.A. and Fichman, M. (1988). 'Dynamics of interorganizational attachments: auditor-client attachments'. Administrative Science Quarterly, 33 (3): 345-369.

Louwers, T. (1998). 'The relation between going-concern opinions and the auditor's loss function'. Journal of Accounting Research, 36 (Spring): 143-156.

Maddala, G.S. (1991). 'A perspective on the use of limited dependent and qualitative variables models in accounting research'. Accounting Review, 66 (4): 788-807.

Magee, R. and Tseng, M. (1990). 'Audit pricing and independence'. Accounting Review, 65 (2): 315-336.

Matsumara, E., Subramanyam, K. and Tucker, R. (1997). 'Strategic auditor behaviour and going-concern decisions', Journal of Business Finance and Accounting, 24 (6):727-758.

Melumad, N. and Thoman, L. (1990). 'On auditors and the courts in an adverse selection setting'. Journal of Accounting Research, 28 (Spring): 77-120.

Menon, K. and Schwartz, K.B. (1985). 'Auditor switches by failing firms'. Accounting Review, April: 248-261.

Menon, K. and Schwartz, K.B. (1987). 'An empirical investigation of audit qualification decisions in the presence of going-concern uncertainties'. Contemporary Accounting Research, Spring: 302-315.

Meuwissen, R. (1999). The economics of auditor careers and audit markets. Ph.D dissertation, Universiteit Maastricht.

Mueller, G.G., Gernon, H. and Meek, G. (1994). Accounting: An International Perspective. Irwin: Burr Ridge.

Mutchler, J.F. (1984). 'Auditors' perceptions of the goingconcern opinion decision'. Auditing: A Journal of Practice and Theory, 3 (Spring): 17-30.

Mutchler, J.F. (1985). 'A multivariate analysis of the audi- 
tor's going-concern opinion decision'. Journal of Accounting Research, Autumn: 668-682.

Nobes, C. (1993). 'The true and fair view requirement: impact on and of the Fourth Directive'. Accounting and Business Research, 24 (93): 35-48.

Nogler, G.E. (1995). 'The resolution of auditor going-concern opinions'. Auditing: A Journal of Practice and Theory, 14 (Fall): 54-73.

Ooghe, H. en Van Wymeersch, C. (1991). Financiële analyse van ondernemingen. Antwerpen: Kluwer.

Ooghe, H., Joos, P. and de Bourdeaudhuij, C. (1995). 'Financial distress models in Belgium: the results of a decade of empirical research'. International Journal of Accounting Education and Research, 30 (Spring): 245-274.

Palmrose, Z. (1988). 'An analysis of auditor litigation and audit service quality'. Accounting Review, 63 (1): 55-73. Pong, C. and Whittington, G. (1994). 'The determinants of audit fees: some empirical models'. Journal of Business, Finance and Accounting, 21 (8): 1071-1095.

Raghunandan, K. and Rama, D.V. (1995). 'Audit reports for companies in financial distress: before and after SAS No.59'. Auditing: A Journal of Practice and Theory, Spring: 50-63.

Vanstraelen, A. (1999). 'The auditor's going-concern opinion decision: a pilot study'. International Journal of Auditing, 3: 41-57.

Vanstraelen, A. (2000). 'Impact of renewable long-term audit mandates on audit quality'. European Accounting Review, 9 (3): 419-442.

Watts, R. and Zimmerman, J. (1986). Positive Accounting Theory. New York: Prentice-Hall. 
Copyright of Accounting \& Business Research is the property of Croner.CCH Group Limited. The copyright in an individual article may be maintained by the author in certain cases. Content may not be copied or emailed to multiple sites or posted to a listserv without the copyright holder's express written permission. However, users may print, download, or email articles for individual use. 